\title{
PENGGUNAAN METODE 3-IN-1 BERBANTUAN CTL UNTUK MENINGKATKAN KETERAMPILAN MEMBUAT POLA DASAR KONSTRUKSI SISWA KELAS X BUSANA 3 SMK NEGERI 6 SEMARANG
}

\author{
THE USE OF CTL AIDED 3-IN-1METHOD TO IMPROVE THE CON- \\ STRUCTION OF BASIC PATTERN MAKING SKILL FOR FASHION \\ DESIGN STUDENTS GRADE X GROUP 3OF STATE VOCATIONAL \\ SCHOOL (SMKN) 6 SEMARANG
}

\author{
Sri Murnisari \\ SMK Negeri 6 Semarang \\ Sariayiktp@gmail.com \\ Naskah diterima: 03 Juli 2019; direvisi: 29 Agustus 2019; disetujui: 29 November 2019
}

\begin{abstract}
ABSTRAK
Pembuatan pola dasar membutuhkan 9 sampai 16 ukuran. Metode 3-in-1 menjadi solusi penyederhanaan dengan 4 ukuran meliputi lebar bahu, lingkar badan, lingkar pinggang dan lingkar panggul. Penelitian Tindakan Kelas dilakukan di SMKN 6 Semarang. Subyek penelitian siswa kelas X Busana 3. Penelitian dilakukan dalam 2 siklus, meliputi planning, acting, observing, dan reflecting. Pembuatan pola dasar konstruksi busana wanita dengan metode 3-in-1, memiliki kelebihan dalam setiap pembuatan pola menghasilkan 3 macam pecahan pola yaitu blus, rok dan gaun. Hasil implementasi menunjukan peningkatan. Perolehan nilai rata-rata saat kondisi awal 73,89. Nilai di atas KKM (standar minimal KKM=75) berjumlah 10 siswa $(29,41 \%)$, sesuai KKM 4 siswa $(11,77 \%)$ dan 20 siswa $(58,82 \%)$ memperoleh nilai di bawah KKM. Hasil siklus I menunjukkan perbaikan, nilai rata-rata klasikal 79,41, nilai di atas KKM 22 siswa (64,70\%), 5 siswa (14,71\%) mendapat nilai KKM dan masih 7 siswa (20,59\%) mendapat nilai di bawah KKM. Pada siklus II menunjukkan perbaikan dari siklus I, nilai ratarata klasikal 87,01, nilai di atas KKM 34 siswa (100\%). Temuan ini menggambarkan bahwa implementasi metode 3-in-1 berbantuan CTL dapat meningkatkan kualitas pembelajaran Pembuatan Pola di SMKN 6 Semarang.
\end{abstract}

Kata Kunci: Metode 3-in-1, Pola dasar konstruksi, Kualitas pembelajaran.

\begin{abstract}
Making basic pattern need 9 until 16 measure. By 3 in 1 method become simplification solution, enaugh taking 4 measurement, consists of shoulder's wide, chest, circumference of waist and hip. SMKN 6 Semarang using the classroom-based action research. The subject is student of fashion grade $X-3$. The research is done on two cycles, consists of planning, acting, observing and reflecting. Making basic construction pattern by 3 in 1 method has benefit that every pattern has 3 kind of slice pattern, blouse, skirt and gown. Implementation result is showing increase. Former average score is 73,89 with 10 students $(29,41 \%)$ get score above the limit, 4 students $(11,77 \%)$ score limit is 75 , rest 20 students $(58,82 \%)$. The first cycle shows an
\end{abstract}


improvement which is the average score increase 79,41 and 22 students (64,70\%) pass the limit, 5 students $(14,71 \%)$ get score limit, rest 7 students $(20,59 \%)$. The second cycle shows more improvement, average score is 87,01 with 34 student (100\%) pass the score limit. This founding describe that the implementation of 3in1 method with aid CTL could increase the learning quality of making pattern in SMKN 6 Semarang

Keyword: 3-in-1 Method, Construction of Basic Pattern, Learning quality.

\section{PENDAHULUAN}

Mata pelajaran Pembuatan Pola merupakan salah satu mata pelajaran produktif yang diberikan dari kelas X sampai XII. Bertujuan agar siswa memiliki kemampuan membuat pola konstruksi busana, khususnya busana wanita. Pada awal pertemuan di kelas $\mathrm{X}$, siswa dijelaskan detail beberapa teknik pengambilan ukuran secara demonstratif menggunakan pass pof ataupun dengan model siswa sendiri. Selanjutnya, siswa mengambil ukuran secara bergantian dengan temannya. Untuk kegiatan tersebut, siswa harus menghafal sambil melakukan minimal 9 sampai 12 kali pengambilan ukuran yang berbeda-beda. Bagian-bagian yang harus diambil ukurannya adalah 1) lingkar leher, 2) lingkar badan, 3) lingkar pinggang, 4) lingkar panggul, 5) lebar dada, 6) panjang dada, 7) lebar bahu, 8) lebar punggung, 9) panjang punggung, 10) tinggi dada. 11) jarak dada, 12) kerung lengan, 13) tinggi puncak lengan, 14) panjang lengan, 15) lebar lengan, 16) panjang blus, dan 17) panjang rok. Pada saat pengambilan ukuran-ukuran dibutuhkan ketrampilan dan ketelitian sesuai bentuk badan model. Kegiatan selanjutnya, guru mengoreksi ketepatan hasil ukuran yang telah dilakukan siswa satu persatu. Data ukuran yang sudah dilakukan dicatat untuk pembuatan pola dasar.

Proses pembelajaran pembuatan pola selama ini hanya menggunakan buku pelajaran, sehingga untuk menyelesaikan tugas-tugas mata pelajaran siswa cenderung textbook oriented, menghafalkan banyak materi yang terdapat pada buku. Selama kegiatan pembelajaran, metode pembuatan dasar pola busana wanita yang dirujuk adalah Meyneke, Praktis, Bunka, So-en, Dressmaking, Cuppens Geurs, Charmant, Danckaerts, dan Soekarno. Sebanyak 7 metode pola telah dibuat diantaranya tersebut di atas oleh Fitinline, 2019. Namun demikian, selama implementasi mata pelajaran tersebut ditemui beberapa kendala, diantaranya a) kesulitan menghafal nama-nama bagian badan yang harus diambil ukurannya karena terlalu banyak, b) kesulitan memahami teknik proses cara pengambilan ukuran di setiap bagian yang berbeda-beda, c) kesulitan memahami banyaknya ukuran badan model yang harus diambil ukurannya, d) hitungan hasil jumlah pembagian yang rumit dalam proses pembuatan pola dasarnya, e) waktu yang lama dalam proses tahapan pembuatan pola dasar, f) menimbulkan adanya ketidakmandirian untuk berkreatifitas, g) sering terlambatnya waktu dalam pengumpulan tugas. Adanya kelemahan metode tersebut dan kurangnya kemampuan memahami serta ketrampilan siswa yang tidak sama dalam menerima materi, maka kegiatan belajar mengajar menjadi tidak kondusif dan kurang efektif. Selama kegiatan belajar, terjadi jeda waktu untuk menunggu guru mengoreksi hasil 
pekerjaan secara personal bergantian dari siswa satu ke siswa lainnya. Ketidakmampuan menyelesaikan tugas dengan baik menjadikan kondisi belajar siswa tidak nyaman.

Dampak proses pembelajaran tersebut, pada umumnya siswa beranggapan bahwa pembuatan pola dasar busana wanita secara konstruksi sulit dipelajari dan menghabiskan waktu lama dalam pembuatannya, Hal tersebut tersurat pada akhir proses pembelajaran yang menggambarkan hasil pembelajaran rata-rata kelas masih banyak yang tidak memenuhi batas minimal nilai KKM(Kriteria Ketuntasan Minimum) yang diharapkan, yaitu skor $\geq 70$. Metode 3-in-1merupakan integrasi teknik pengukuran berupa penggabungan dan penyesuaian ukuran-ukuran utama badan manusia. Teknik tersebut meliputi empat (4) macam pengukuran yaitu lebar bahu, lingkar badan, lingkar pinggang, dan lingkar panggul. Teknik pembuatan dasar pola ini memiliki kelebihan diantaranya a) kemudahan untuk menghafal nama bagianbagian yang harus diukur meliputi lebar bahu, lingkar badan, lingkar pinggang dan lingkar panggul, b) mampu melakukan teknik pengambilan ukuran dengan benar, karena jelas bagian yang akan diambil ukurannya, c) proses tahapan langkah demi langkah dalam pembuatan pola dasar mudah diikuti dan dilakukan siswa, d) waktu pembuatan lebih cepat, e) mampu membuat sendiri, f) memiliki ketrampilan berbasis life skill. Kemampuan dan keterampilan hasil belajar akan tetap terpakai, sekalipun mereka telah lulus SMK sebagai modal wirausaha, bekerja secara mandiri, ataupun bekerjasama dengan orang lain. Metode 3-in-1 merupakan solusi kemudahan dalam pembuatan pola dasar konstruksi. Adanya penyederhanaan dalam pengambilan ukuran. Empat (4) macam ukuran badan terdiri dari lebar bahu, lingkar badan, lingkar pinggang dan lingkar panggul. Keempat ukuran ini mampu mewakili dalam pembuatan pola dasar konstruksi busana wanita. Proses pembuatan pola tidak hanya menghasilkan satu pola dasar saja melainkan mendapat 3 pecahan pola dasar. Adapun pecahan pola dasar itu terdiri dari pola blus, pola rok dan pola gaun. Apapun ukuran yang dipakai maka pola dasar konstruksi akan menghasilkan 3 macam pola dasar. Dengan demikian, siswa dapat belajar secara mandiri dan mampu meningkatkan kreativitasnya.

\section{KAJIAN LITERATUR \\ Pengertian Belajar dan Mengajar}

Pengertian belajar adalah suatu proses usaha yang dilakukan seeorang untuk memperoleh suatu perubahan tingkah laku yang baru secara keseluruhan, sebagai hasil pengalamannya sendiri dalam interaksi dengan lingkungannya (Slameto, 2013; Ahmad, 2012).Belajar adalah modifikasi atau memperteguh kelakuan malalui pengalaman (learning is defined as the modification or strengthening of behavior through experiencing). Belajar merupakan suatu proses, suatu kegiatan bukan suatu hasil atau tujuan. Belajar bukan hanya mengingat tetapi lebih luas dari itu, yakni mengalami. Hasil belajar bukan suatu penguasaan hasil latihan melainkan pengubahan kelakuan (Hamalik, 2008). Teori belajar menurut pandangan Bloom dan Krathwohl (Budiningsih, 2008), mereka lebih menekankan perhatiannya pada apa yang mestinya dikuasai oleh individu sebagai tujuan belajar, setelah melalui peristiwa-peristiwa belajar. Tujuan belajarnya dirangkum dalam tiga kawasan yang dikenal 
dengan Taksonomi Bloom yang terdiri dari Domain Kognitif, Domain Afektif dan Domain Psiko-motor. Pendapat yang sama dikemukakan (Arifin, 2012) menjabarkan proses mengajar adalah a) suatu rangkaian perbuatan guru dan siswa atas dasar hubungan timbal balik yang berlangsung dalam situasi edukatif untuk mencapai tujuan tertentu, b) rentetan tahapan atau fase dalam mempelajari sesuatu, c) rentetan kegiatan perencanaan oleh guru, pelaksanaan kegiatan sampai evaluasi dan program tindak lanjut, d) pembelajaran pelajar yang dilakukan melalui interaksi perilaku pengajar dan pelajara, baik di dalam maupun di luar kelas, e) proses penciptaan sistem lingkungan yang memungkinkan terjadinya proses belajar .

\section{Model Quantum Teaching and Learning}

Quantum Teaching oleh A'la (2010), dikemukakan seperti orkestrasi bermacammacam interaksi yang ada di dalam dan di sekitar situasi belajar. Interaksi ini mencakup unsur-unsur untuk belajar efektif yang mempengaruhi kesuksesan siswa, mengubah kemampuan dan bakat alamiah siswa menjadi cahaya yang akan bermanfaat bagi mereka sendiri dan orang lain. Kolaborasi interaksi balajar yang terdiri dari konteks dan konten. Konteksnya meliputi 1) suasana pembelajaran, 2) landasan / kerangka kerja, 3) lingkungan pembelajaran, 4) perancangan pembelajaran yang dinamis, 5) presentasi/ cara penyampaian materi, 6) pemberdayaan fasilitas, 7) ketrampilan hidup, 8) praktik. Guru adalah tenaga pendidik profesional dengan tugas utama, mendidik, mengajar, membimbing, mengarahkan, melatih, menilai, mengevaluasi (Aqib, 2007). Gagne $\&$ Briggs, guru bukan sebagai penyampai informasi tetapi bertindak sebagai director $\&$ fasilitator oflearning - pengarah dan pemberi fasilitas untuk terjadinya proses belajar (Ali, 2007). Guru seringkali menggunakan insentif untuk memberi motivasi kepada siswa untuk mencapai tujuan pengajaran. Misalnya memberi pujian pada siswa, memberi penghargaan, memberi angka atau nilai, memberi harapan dan peluang. Oleh karena itu, guru harus kreatif, imajinatif dan inovatif dalam menyediakan insentif yang tepat bagi para siswa. Untuk memuaskan dorongan ini guru harus memberi semangat kepada mereka (siswa), antara lain dengan cara: 1) membantu setiap siswa sampai dia sukses, 2) membebaskan siswa dari keterbelakangan, 3) mendorong kemauan untuk maju dan berkembang, 4) mengembangkan kemampuan, pengetahuan, ketrampilan secara optimal (Domein Kognitif, Afektif - Psikomotor), 5) melakukan dampingan secara berkala, 6) memberikan bimbingan, konseling dan latihan pada siswa (Hamalik, 2007). Quantum Teaching membantu guru menggabungkan keistimewaan belajar menjadi sebuah multisensori, multi kecerdasan, kompatibel dengan otak, yang pada akhirnya meningkatkan kemampuan guru untuk memotivasi siswa berprestasi.

Quantum Learning menjadi model pembelajaran yang sangat efektif mendukung prosesbelajaryangnyamandanmenyenangkan bagi siswa.. Penerapan Quantum Learning dalam pembelajaran membantu siswa dalam meningkatkan motivasi, nilai belajar, percaya diri dan kehormatan diri, bersikap posif dan mampu mengembangkan ketrampilan yang dimilikinya. Upaya untuk menanamkan nilainilai dan keyakinan yang positif itu, maka perlu memperbaiki cara belajar diantaranya, 
1) melatih Fisik, berupa gerakan,terobosan, perubahan keadaan, permainan, fisiologi, estafet, partisipasi, 2) menciptakan suasana nyaman, cukup penerangan, enak dipandang, adamusiknyauntukreleks, 3)mengkondisikan lingkungan yang positif, aman, mendukung, santai, penjelajahan (exploratory), 4) menggali sumber belajar dengan melakukan interaksi berupa pengetahuan, pengalaman, hubungan korelasi, dan inspirasi, 5) belajar untuk mempelajari ketrampilan seperti menghafal, membaca, menulis, mencatat, cara belajar, kreativitas dan komunikasi, 6) menerapkan beberapa belajar metode seperti permainan,simulasi, simbol dan mencontoh. Penggunaan media pembelajaran bagian dari penerapan Quantum Learning untuk meningkatkan keterampilan siswa dalam pembuatan pola busana. Sebagaimana Himmah YF, (2014) menerapkannya dalam pembuatan busana rumah. Begitu juga Gultom DT, (2012) dengan media flipchart untuk pembuatan pola dasar busana wanita. Sedangkan Ningrum PK, (2013) dengan media video untuk pembuatan pola blus. Pendekatan Quantum Learning terlihat pula pada model pembelajaran Cooperative learning. Seperti yang diungkapkan oleh (Elly S,2013; Erniaty, 2017) dalam pembuatan pola. Setiap siswa anggota kelompok harus saling bekerja sama dan saling membantu untuk memahami materi pelajaran. Dalam pembelajaran kooperatif, belajar dikatakan belum selesai jika salah satu teman dalam kelompok belum menguasai bahan pelajaran. Namun demikian masih harus diberikan solusi untuk kemudahkan dalam menyelesaiak materi tugas. Khususnya pembuatan pola dasar konstruksi busana, penerapan metode 3-in1 menjadi alternatif yang perlu disampaikan dalam proses pembelajaran praktek. Hal senada diungkapkan pula oleh Sugiarti E, (2014). Pengembangan pembelajaran yang efektif perlu didasarkan pada pemahaman tentang bagaimana siswa belajar atau mengalami perubahan tingkah laku. Sebab, berhasil tidaknya pencapaian tujuan pembelajaran sangat bergantung kepada bagaimana proses belajar itu terjadi pada siswa. 'Models of teaching are really models of learning'. Penggunaan metode 3-in-1 dengan berbantuan pendekaatan Quantum Teaching dan Quantum Learning sebagai upaya pemenuhan kebutuhan siswa dan perkembangan psikologi siswa khususnya kelas X.

\section{Strategi pembelajaran Contextual Teaching and Learning}

Pembuatan pola dasar busana wanita dalam penelitian ini menerapkan pendekatan pembelajaran Contextual Teaching and Learning (CTL). Contextual Teaching and Learning(CTL) memiliki konsep diantaranya proses keterlibatan siswa. 1)CTLmenekankan kepada proses keterlibatan siswa untuk menemukan materi, artinya proses belajar diorientasikan pada proses pengalaman secara langsung, 2) CTL mendorong agar siswa dapat menemukan hubungan antara materi yang dipelajari dengan situasi kehidupan nyata, 3) CTL mendorong siswa untuk dapat menerapkannya dalam kehidupan ,artinya CTL bukan hanya mengharapkan siswa dapat memahami materi yang dipelajari, akan tetapi bagaimana materi pelajaran itu dapat mewarnai perilakunya dalam kehidupan sehari-hari (Kesuma, 2010). Strategi pembelajaran CTL memiliki asasasas diantaranya. 
Penerapan pendekatan CTL diharapkan lebih bermakna bagi siswa. Selama proses pembelajaran, siswa dapat menghubungkan materi yang mereka pelajari dengan kondisi nyata sehari-hari. Belajar lebih bermakna jika siswa mengalami apa yang dipelajarinya, bukan semata-mata mengetahuinya saja. Siswa dengan sadar akan mengerti apa makna belajar dan manfaatnya di kemudian hari. Seperti halnya Rusmalanur I, (2016) dalam pembuatan pola dengan menggunakan metode picture and picture merupakan salah satu pendekatan quantum learning berupa permaianan simulasi dan simbul untuk memotivasi belajar siswa. Yulita M, (2015) dalam pembuatan pola gaun dengan dilakukan secara berkelompok merupakan penerapan pendekatan CTL. Metode 3-in-1 berbantuan CTL merupakan solusi yang sangat membantu pada saat proses belajar. Pendekatan yang diterapkan dalam pembelajaran Pembuatan Pola sudah seharusnya memberikan ruang gerak dan kesempatan kepada siswa untuk menggali kemampuan dan mengembangkan kreativitas, kemampuan dan keterampilannya, secara tidak langsung mengajarkan siswa tentang learning how to learn (belajar bagaimana mempelajari sesuatu). Guru menjadi model pengembangan sikap belajar siswa. Hubungan antara guru dan siswa merupakan hubungan yang interaktif sehingga siswa merasa aman dan nyaman (joyful learning) dalam proses belajarnya. Dengan demikian, siswa akan terlatih untuk selalu berupaya mengembangkan penalaran dan kreativitasnya dalam rangka pengembangan kemampuan dirinya. Penerapan metode 3-in1 berbantuan CTL sangat membantu siswa kelas X Busana 3 di SMK Negeri 6 Semarang dalam meningkatkan ketrampilan pembuatan pola dasar konstruksi busana.

\section{METODE PENELITIAN}

Metode penelitian yang akan digunakan pada penelitian kelas ini adalah tindakan kelas (Classroom-based Action Research). Secara skematis rancangan penelitian ini dapat dilihat pada gambar 1 .

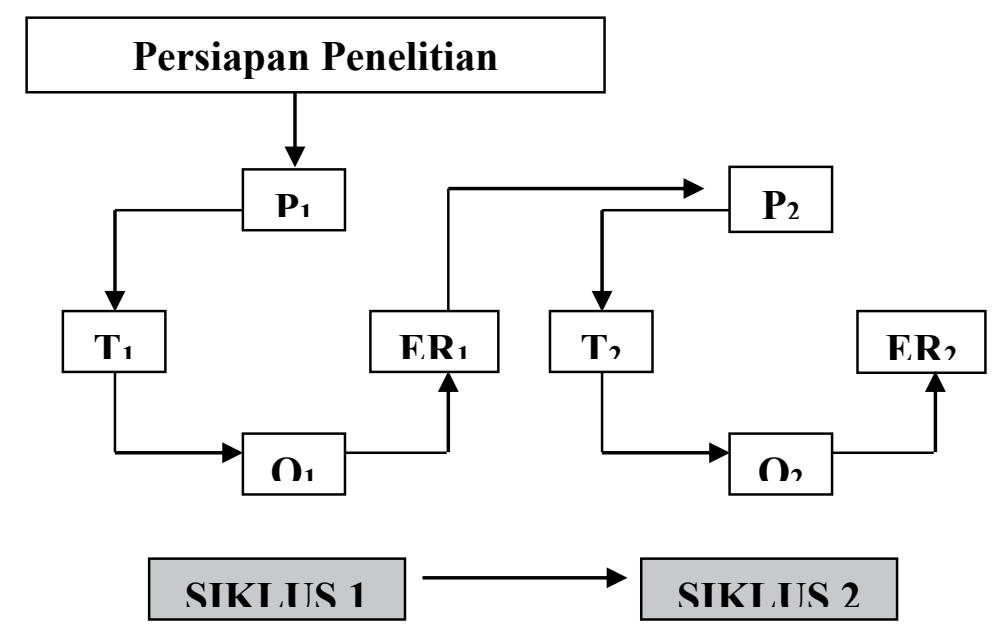

Gambar 1. Desain Penelitian

Keterangan:

$\mathrm{P} \quad$ : Perencanaan tindakan $\mathrm{O}$ : Observasi

$\mathrm{T}$ : Pelaksanaan tindakan ER : Evaluasi-Refleksi 
Penelitian dilaksanakan secara bersiklus. didapat siswa dengan nilai $\geq 75$ hanya Setiap siklus terdiri dari 2 kali pertemuan, dan berjumlah 41, 18\%. 2). Pelaksanaan Siklus disetiap pertemuan meliputi 4 jam pelajaran. 1 menerangkan pembuatan pola dasar Setiap siklus terdiri dari 4 tahapan, yaitu konstruksi dengan metode 3-in-1. Pada tahap perencanaan, pelaksanaan tindakan, pengamatan dan refleksi. Secara keseluruhan, pertemuan ke-1 membuat pola dasar dengan ukuran Small (S). Pada pertemuan ke-2 materi membuat pola dasar dengan ukuran 1, pertemuan ke-1 membuat pola dasar konstruksi busana ukuran "S". Pertemuan ke-2, membuat pola dasar konstruksi busana ukuran "M". Siklus 2 di pertemuan ke-1 membuat pola dasar konstruksi busana ukuran "L". Pertemuan ke-2 membuat pola dasar konstruksi busana ukuran "XL". Variabel yang akan diteliti pada penelitian ini adalah variabel input,variabel proses, dan variabel output.

Tindakan penelitian akan dilakukan sebagai berikut 1) Kondisi awal, guru menerangkan urutan kerja gambar pola dasar konstruksi untuk busana wanita dengan metode Mayneke. Sesuai job sheet dari menyiapkan alat dan bahan. Selanjutnya siswa meniru dan hasil yang M. Cara pengambilan ukuran, daftar ukuran dan langkah-langkah cara pembuatan pola dasar konstruksi metode 3-in-1 terlampir. 3) Pelaksanaan Siklus 2, siswa mulai terampil membuat pola dasar konstruksi dengan langkah-langkah yang benar. Daftar ukuran L dan XL serta cara pembuatan pola dasar konstruksi sama langkah-langkahnya seperti di siklus 1 , hanya berbeda pada ukuran bahu, lingkar badan, lingkar pinggang dan lingkar panggul. Pada pertemuan ke-1 membuat pola dasar dengan ukuran Large (L) dan untuk pertemuan yang ke-2 membuat ukuran Extra Large (XL). Selama kegiatan pada pelaksanaan siklus ke-2 siswa sudah dapat membuat tugas dengan lebih cepat waktu penyelesaiannya.
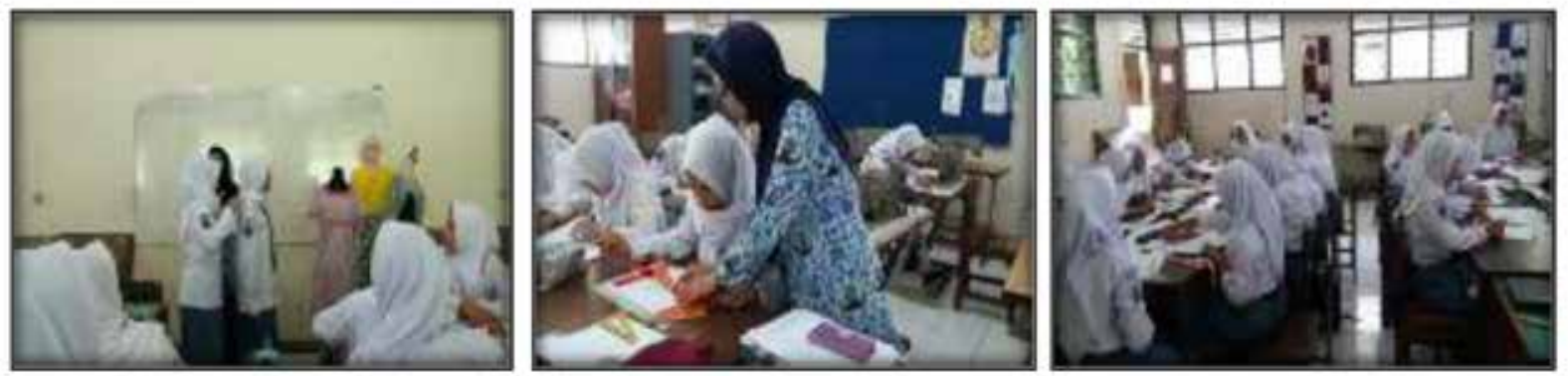

Gambar 2. Kegiatan penelitian di kelas - Siklus 1 


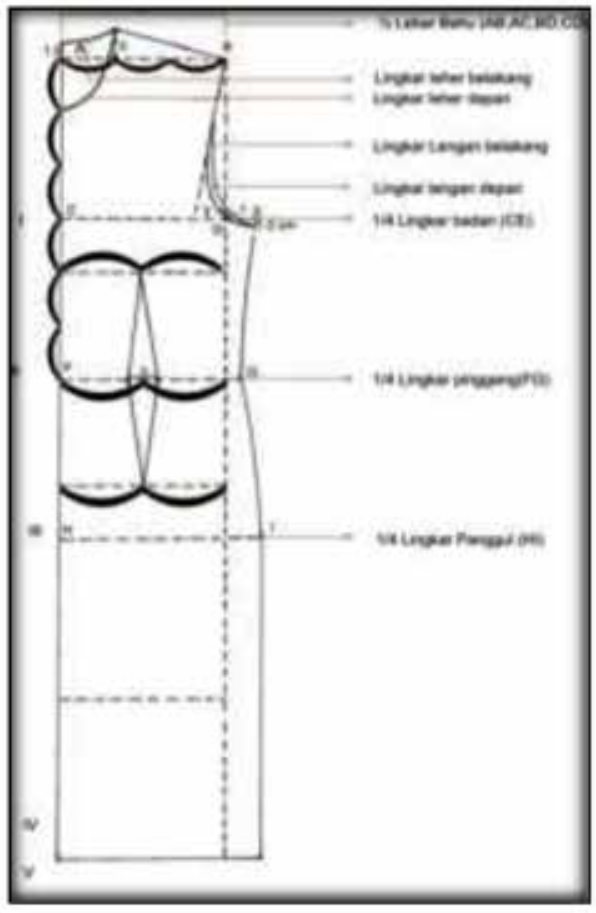

Gambar 3. Hasil temuan pola dasar konstruksi busana dengan metode 3-in-1.
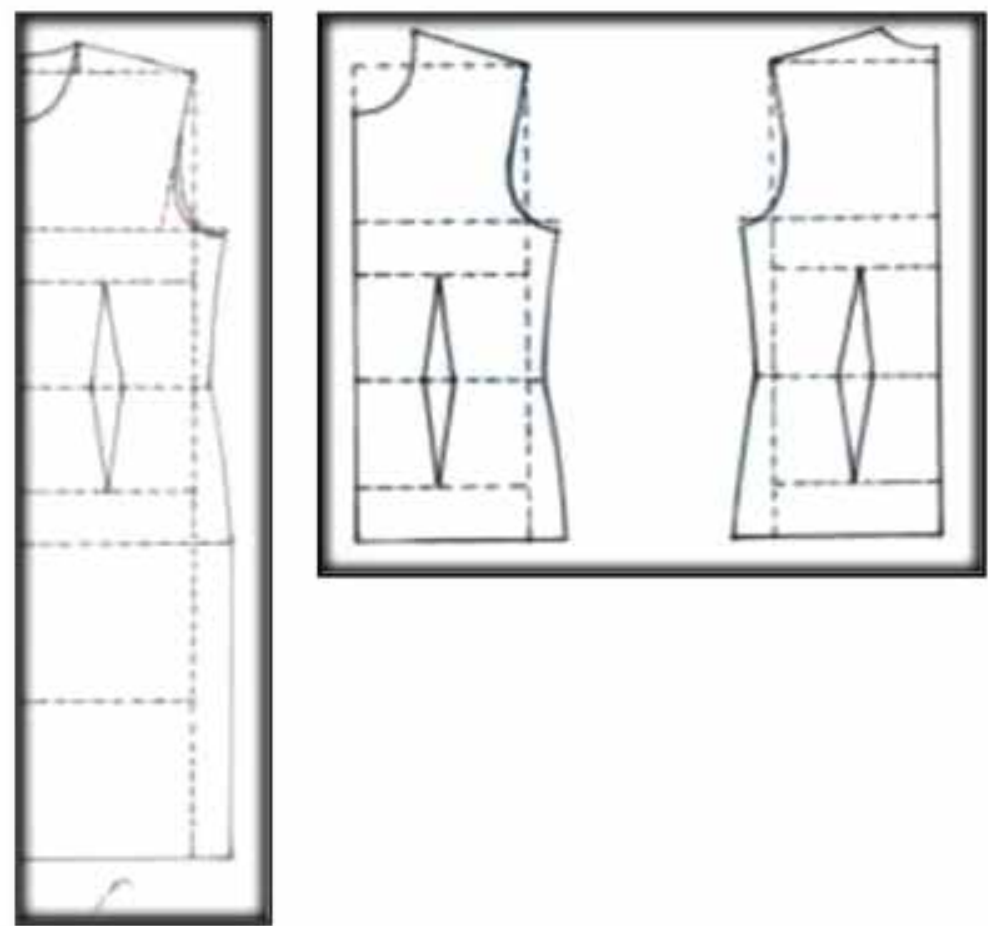

Gambar 4. Hasil pecahan ke-1 dari pola dasar konstruksi busana metode 3-in-1 berupa pola dasar blus 


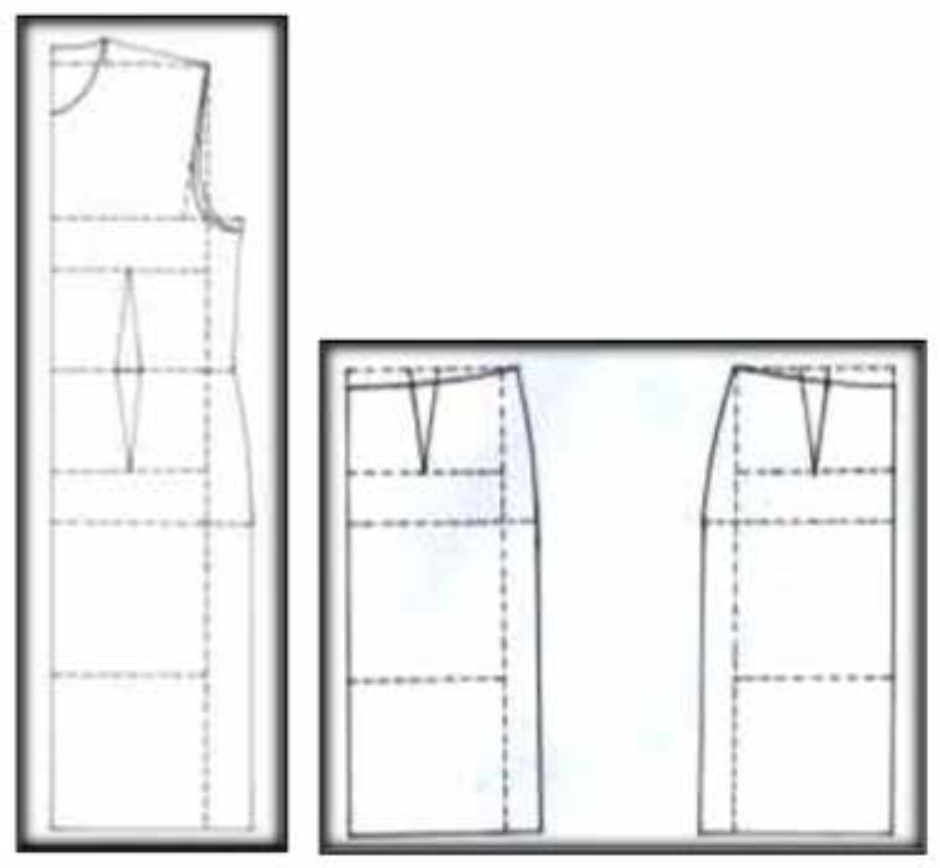

Gambar 5. Hasil pecahan ke-2 dari pola dasar konstruksi busana metode 3-in-1 berupa pola dasar rok
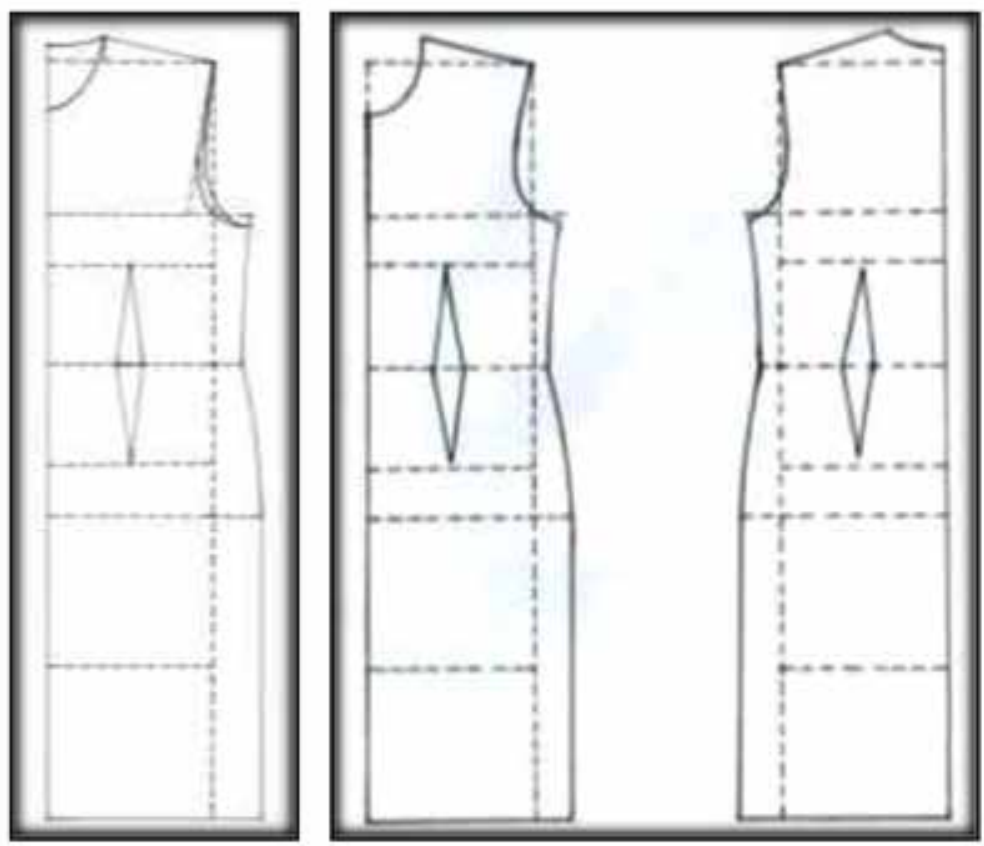

Gambar 6. Hasil pecahan ke-3 dari pola dasar konstruksi busana metode 3-in-1 berupa pola dasar gaun 

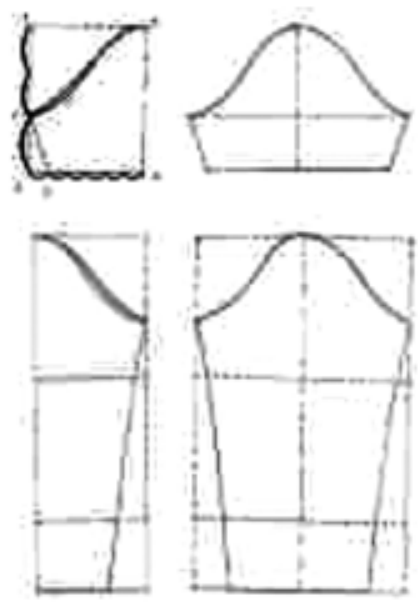

Gambar 7. Hasil pecahan pola dasar konstruksi busana metode 3-in-1 berupa lengan pendek dan lengan panjang
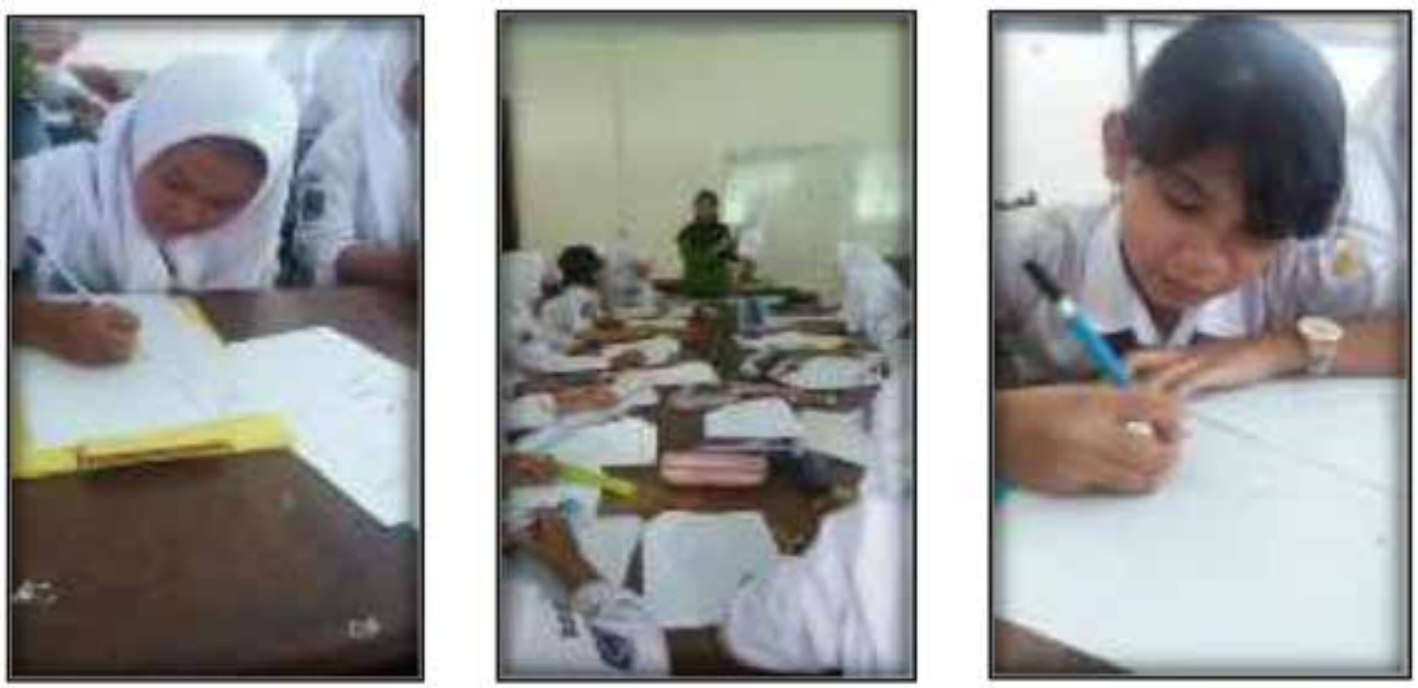

Gambar 8. Kegiatan penelitian di kelas - Siklus 2

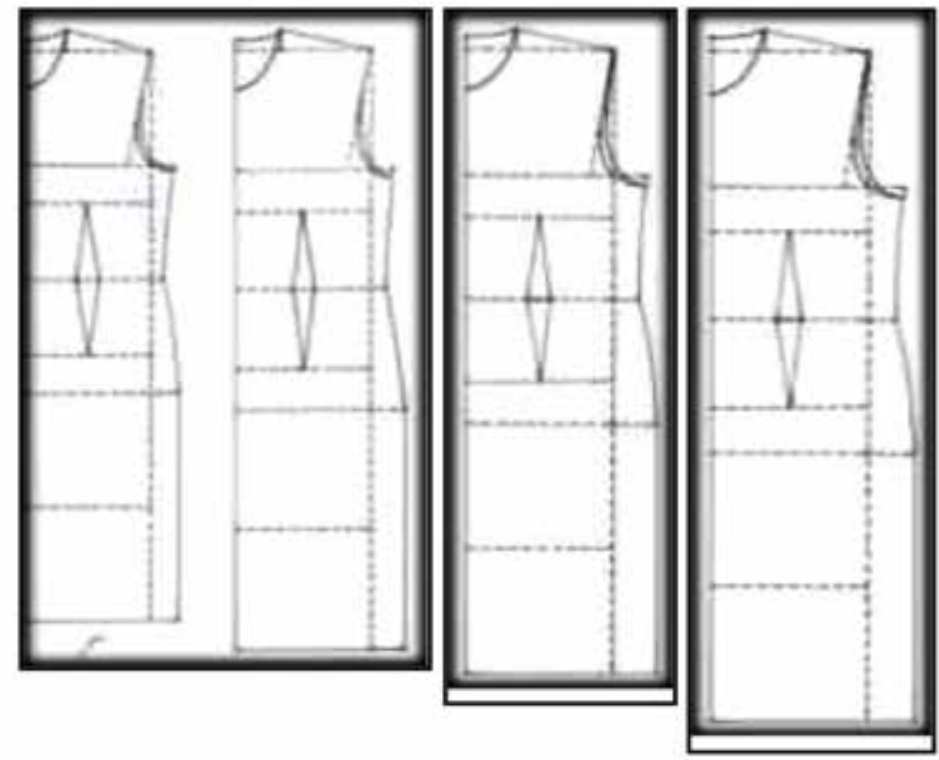

Gambar 9. Hasil pola dasar konstruksi busana metode 3-in-1 ukuran S, M , L dan XL 
Penelitian ini dilaksanakan di SMK Negeri 6, Jl. Sidodadi Barat No. 8 Semarang pada bulan Maret - Mei 2018. Subyek penelitian adalah siswa kelas X Busana 3 jurusan Tata Busana SMK Negeri 6 Semarang Tahun Pelajaran 2017/2018. Populasi penelitian terdiri dari 34 orang siswa homogen perempuan. Untuk keperluan observasi dan pendataan pendapat melalui angket, diambil 17 orang sebagai subjek dengan rincian 5 siswa tergolong berkemampuan tinggi, 5 siswa tergolong kemampuan rata-rata, 7 siswa tergolong kemampuan rendah.

Tabel 1. Subjek penelitian

\begin{tabular}{clc}
\hline No. & \multicolumn{1}{c}{ Kegiatan Penelitian } & Jumlah siswa \\
\hline 1. & Tes praktik & 34 siswa \\
\hline 2. & $\begin{array}{l}\text { Observasi } \\
\text { (aktivitas siswa di kelas) }\end{array}$ & $\begin{array}{c}17 \text { dari } 34 \\
\text { siswa }\end{array}$ \\
\hline 3. & $\begin{array}{l}\text { Angket } \\
\text { (pendapat siswa tentang } \\
\text { angket) }\end{array}$ & $\begin{array}{c}\text { 34 dari 34 } \\
\text { siswa }\end{array}$ \\
\hline
\end{tabular}

Teknik pengumpulan data pada penelitian ini menggunakan tiga bentuk instrumen yaitu tes, lembar penilaian peningkatan kemampuan, lembar observasi, dan angket. 1) Tes akan digunakan untuk mengetahui tingkat penguasaan materi yang berkaitan dengan materi pengambilan ukuran badan sampai pembuatan pola dasar konstruksi busana wanita, 2) Lembar observasi digunakan untuk mengambil data kinerja siswa selama proses pembelajaran. Adapun aspek yang diamati adalah aktivitas siswa selama proses belajar berlangsung, 3) Angket digunakan untuk menjaring data berkaitan dengan motivasi dan kepuasan siswa selama proses pembelajaran.

Teknik analisis data diperoleh dari hasil observasi dan penilaian dari setiap siklus akan dianalisis secara kuantitatif dan diskriptif. Teknik analisis data dapat dilihat pada Tabel 2. Jadwal pelaksanaan penelitian dapat dilihat pada tabel 3 .

Tabel 2. Hubungan data, instrumen, dan teknik analisis

\begin{tabular}{|c|c|c|c|}
\hline No. & Data & Instrumen & Analisis data \\
\hline 1. & 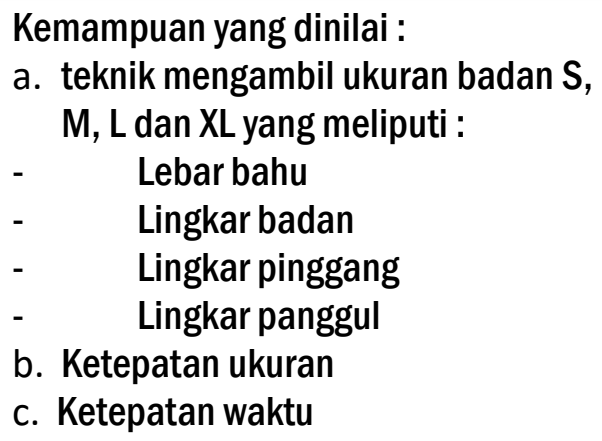 & $\begin{array}{l}\text { Tes praktik dalam pembuatan } \\
\text { pola dasar konstruksi sesuai } \\
\text { ukuran badan model }\end{array}$ & $\begin{array}{l}\text { Standar } \\
\text { penilaian KKM }\end{array}$ \\
\hline 2. & Aktivitas siswa & Lembar observasi & $\begin{array}{l}\text { Kualitatif } \\
\text { Diskriptif }\end{array}$ \\
\hline 3. & $\begin{array}{l}\text { Pendapat siswa tentang pembuatan } \\
\text { pola dasar konstruksi dengan teknik } \\
\text { empat ukuran badan }\end{array}$ & Angket & $\begin{array}{l}\text { Persentase } \\
\text { Deskriptif }\end{array}$ \\
\hline
\end{tabular}


Tabel 3. Jadwal penelitian

\begin{tabular}{|c|l|l|l|l|l|l|l|}
\hline No & \multicolumn{1}{|c|}{ Kegiatan } & Januari & Februari & Maret & April & Mei & Juni \\
\hline 1. & $\begin{array}{l}\text { Penulisan Proposal, } \\
\text { Instrumen Penelitian } \\
\text { dan Pembimbingan } \\
\text { Penyusunan Proposal }\end{array}$ & & & & & & \\
\hline 2. & Pengambilan Data & & & & & & \\
\hline 3. & $\begin{array}{l}\text { Penyelesaian } \\
\text { Administrasi Penelitian }\end{array}$ & & & & & & \\
\hline 4. & Pelaksanaan Penelitian & & & & & & \\
\hline 5. & $\begin{array}{l}\text { Pelaporan Hasil } \\
\text { Penelitian }\end{array}$ & & & & & & \\
\hline
\end{tabular}

\section{HASIL DAN PEMBAHASAN}

Pada kondisi awal hasil pembuatan pola dasar busana 73,89, dengan menggunakan lebih dari 10 ukuran dengan metode pada umumnya. Persentase siswa yang mencapai nilai di atas KKM adalah 10 siswa $(29,41 \%)$ dan masih ada 4 siswa $(11,77 \%)$ sesuai KKM serta ada 2 siswa $(58,82 \%)$ nilai di bawah KKM.

Evaluasi penyebab kekurangan pada pelaksanaan tindakan kondisi awal dapat dianalisis yaitu karena adanya kekurangpahaman siswa tentang banyaknya nama-nama dalam pengambilan ukuran yang dipakai dalam pembuatan pola dasar. Solusi untuk meningkatkan ketrampilan siswa secara bertahap dengan menggunakan metode 3 in 1 dengan berbantuan strategi CTL. Pengambilan ukuran dan nama-nama bagian yang diukur dalam siklus 1 pertemuan ke-1 belum maksimal.

Hasil siklus 1 pertemuan ke-1 didapatkan nilai rata-rataklasikal 79,41 dengan persentase siswa yang mencapai nilai diatas KKM adalah 22 siswa $(64,70 \%), 5$ siswa $(14,71 \%)$ yang mendapat nilai standar minimal KKM, dan masih 7 siswa $(20,59 \%)$ mendapat nilai di bawah KKM. Evaluasi kekurangan dan solusi pada pelaksanaan tindakan siklus 1 pertemuan ke-1 saat dilakukan analisis pada saat pembelajaran berlangsung masih ada siswa yang kurang cepat dalam menghitung. Pada siklus 1 pertemuan ke-2. Siswa sudah mulai mampu mengikuti langkah-langkah pembuatan pola dasar konstruksi. Data yang didapat dari hasil siklus 1 pertemuan ke-2 terlihat ada perkembangan nilai skor. Nilai rata-rata klasikal 81,71 dengan persentase siswa yang mencapai nilai diatas KKM adalah 29 siswa $(85,30 \%)$, masih ada 1 siswa $(2,94$ $\%$ ) yang memperoleh nilai standar minimal KKM, dan tinggal 4 siswa (11,76\%) yang memperoleh nilai di bawah standar minimal KKM.

Penggunaan metode 3 in 1 dalam siklus 2 pertemuan ke-1 dapat membantu siswa dalam menyelesaikan tugas dalam pembuatan pola dasar konstruksi busana dengan hasil skor jauh lebih baik dibandingkan dengan pertemuan sebelumnya. Hasil siklus 2 pertemuan ke-1, nilai rata-rata klasikal adalah 85,26 dengan persentase siswa yang mencapai nilai diatas 
KKM adalah 32 siswa $(94,12 \%)$, dan masih ada 2 siswa $(5,88 \%)$ yang memperoleh nilai standar minimal KKM. Pada siklus 2 pertemuan ke-2, siswa sudah mulai terampil menghitung dan mengikuti urutan langkahlangkah pembuatan pola dasar konstruksi. Data yang didapat dari hasil siklus 2 pertemuan ke-2 terlihat perkembangan nilai skor yang baik. Nilai rata-rata klasikal 88,79 dengan persentase siswa yang mencapai nilai diatas KKM adalah 34 siswa (100\%), dan tidak ada lagi nilai dibawah KKM. Rekapitulasi nilai tes akhir pembelajaran Pembuatan Pola dari kondisi awal, Siklus 1 dan Siklus 2 dengan menggunakan media dapat dilihat pada tabel 4.

Hasil penelitian menunjukkan bahwa penggunaan metode 3 in 1 berbantuan CTL memberikan nuansa baru bagi siswa dalam mengembangkan potensi diri. Kecenderungan peningkatan hasil belajar siswa selama pembelajaran dua siklus penelitian dapat digambarkan pada tabel 5 .

Tabel 4. Rekapitulasi nilai tes akhir pembelajaran Pembuatan Pola

\begin{tabular}{|c|l|c|c|c|c|c|}
\hline \multirow{2}{*}{ No } & \multicolumn{1}{|c|}{ Aspek } & \multirow{2}{*}{ Kondisi awal } & \multicolumn{2}{|c|}{ Siklus I } & \multicolumn{2}{c|}{ Siklus II } \\
\cline { 4 - 7 } & & & Pertemuan ke-1 & $\begin{array}{c}\text { Pertemuan } \\
\text { ke-2 }\end{array}$ & $\begin{array}{c}\text { Pertemuan } \\
\text { ke-1 }\end{array}$ & $\begin{array}{c}\text { Pertemuan } \\
\text { ke-2 }\end{array}$ \\
\hline 1. & Rerata tes & 73,89 & 79,41 & 81,71 & 85,26 & 88,79 \\
\hline 2. & Rerata siklus & \multicolumn{2}{|c|}{80,56} & \multicolumn{2}{|c|}{87,01} \\
\hline 3. & $\begin{array}{l}\text { Ketuntasan klasikal : } \\
\sum \text { siswa } \geq 75 \\
\sum \text { seluruh siswa }\end{array}$ & $41,18 \%$ & $79,41 \%$ & $88,23 \%$ & $100 \%$ & $100 \%$ \\
\hline
\end{tabular}

Tabel 5. Hasil nilai siswa pada kondisi awal, siklus I dan siklus II

\begin{tabular}{|c|c|c|c|c|}
\hline Keterangan & Rerata nilai & $\begin{array}{c}\text { Nilai } \\
\text { di atas KKM }\end{array}$ & Nilai Tertinggi & Nilai Terendah \\
\hline Kondisi awal & 73,89 & 14 siswa & 86 & 64 \\
\hline Siklus 1 & 80,56 & 30 siswa & 91 & 73 \\
\hline Siklus 2 & 87,01 & 34 siswa & 100 & 76 \\
\hline
\end{tabular}

Peningkatan hasil belajar siswa dapat dilihat pada gambar grafik di bawah ini:

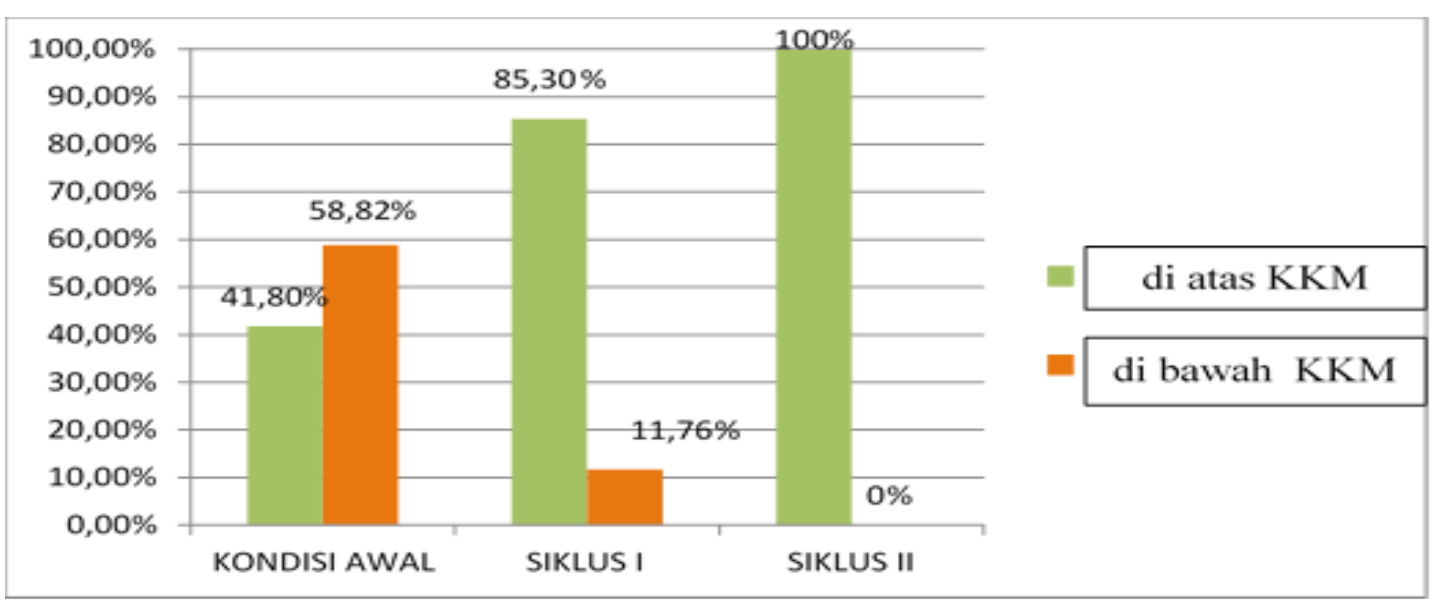

Gambar 10. Peningkatan hasil belajar siswa 
SIMPULANDANUSULANKEBIJJAKAN Simpulan

Metode 3-in-1 merupakan solusi kemudahan dalam pembuatan pola dasar konstruksi. Adanya penyederhanaan dalam pengambilan ukuran. Empat (4) macam ukuran badan terdiri dari lebar bahu, lingkar badan, lingkar pinggang dan lingkar panggul. Keempat ukuran ini mampu mewakili dalam pembuatan pola dasar konstruksi busana wanita. Proses pembuatan pola tidak hanya menghasilkan satu pola dasar saja melainkan mendapat 3 pecahan pola dasar. Adapun pecahan pola dasar itu terdiri dari pola blus, pola rok dan pola gaun. Apapun ukuran yang akan dibuat maka pola dasar konstruksi busana akan menghasilkan 3 macam pola dasar. Dengan demikian, siswa dapat belajar secara mandiri dan mampu meningkatkan kreativitasnya. Penggunaan metode 3-in1 dapat meningkatkan hasil belajar dan keterampilan membuat pola dasar konstruksi busana wanita bagi siswa kelas X Busana
3 Butik SMK Negeri 6 Semarang. Adanya peningkatan nilai di atas nilai KKM dari jumlah 34 siswa, pada kondisi awal hanya $41,18 \%$, kemudian ada peningkatan 85,30\% setelah siklus I, dan meningkat lagi menjadi $100 \%$ pada akhir siklus II.

\section{Usulan Kebijakan}

Metode 3-in-1 dapat dijadikan salah satu alternatif metode inovasi dalam pembelajaran Pembuatan Pola. Guru SMK jurusan tata Busana diharapkan mampu melakukan inovasi pembelajaran dengan mengembangkan metode kreatif untuk memotivasi siswa mengembangkan kemampuan dan keterampilannya. Guru hendaknya mampu menumbuhkan kreativitas siswa melalui pembelajaran yang dikemas berdasarkan student centered learning. Sekolah hendaknya memberikan dukungan baik material maupun motivasi terhadap penggunaan media pembelajaran yang relevan dan menyenangkan.

\section{PUSTAKA ACUAN}

A’la,M. (2010), Quantum Teaching (Buku Pintar dan Praktis), Jogjakarta

Arikunto,S., Suharjono. Supardi. (2012). Penelitian Tindakan Kelas. Jakarta: PT. BumiAksara.

Elly S, (2013) Peningkatan motivasi belajar siswa kelas xi busana 2 pada mata pelajaran membuat pola melalui model kooperatif learning di smkn 6 palembang. Dinas Pendidikan pemuda dan olahraga kota Palembang;

https://google.com/search?q=hasil+ptk+1.+Elly+S\%2C+(2013)+Peningkatan + motivasi+belajar + siswa + kelas $+x i+$ busana $+2+$ pada + mata + pelajaran + membuat + pola + melalui + model + kooperatif + learning + di + smkn $+6+$ palembang. + Dinas + Pendidikan+pemuda + dan + olahraga + kota + Palembang

Erniaty, (2017) Peningkatan Hasil Belajar Produktif Tata Busana (Dasar Pola) Siswa Kelas X Busana - 1 SMKN 10 Medan melalui Penerapan Pembelajaran Kooperatif Tipe Student Team Achievement Division. Guru Produktif Tabus SMKN 10 Medan; 5 (1): p.(35-42).

https://jurnal.uisu.ac.id $>$ keguruan $>$ article $>$ view Fitinline, (2019) 7 Metode pembuatan pola dasar baju dan pengaruhnya terhadap tingkat kenyamanan busana 
https:/fitinline.com/article/read/7-metode-pembuatan-pola-dasar-baju-dan-pengaruhnyaterhadap-tingkat-kenyamanan-busana/

Gultom DT, (2012) Peningkatan Kompetensi dalam Membuat Pola Dasar Busana Wanita menggunakan Media Flipchart berbantuan Jobsheet di SMK Diponegoro Depok Sleman Yogyakarta. Program Studi Pendidikan Teknik Busana Jurusan Pendidikan Teknik Boga dan Busana Fakultas Teknik, Universitas Negeri Yogyakarta;

https://eprints.uny.ac.id/26596/1/duma-trianita-gultom.pdf

Hartono,R. (2013). Ragam Mengajar yang Mudah Diterima Murid. Jogjakarta: DIVA Press,Anggota IKAPI.

Himmah YF, (2014) Penerapan Media sebagai Upaya Meningkatkan Pemahaman \& Keterampilan membuat Pola Busana Rumah di SMKN 3 Kediri. Pendidikan Tata Busana, Fakultas Teknik, Universitas Negeri Surabaya; 3 (1): p.(195-201).

https://jurnalmahasiswa.unesa.ac.id/index.php/jurnal-tata-busana/article/view/6971

Kamus Besar Bahasa Indonesia Pusat Bahasa. (2008). Pusat Bahasa Departemen Pendidikan Nasional dan Balai Pustaka. Jakarta: Balai Pustaka.

Kesuma,D., Hermana,D., Supardan,D., Undang,G. (2010). ContextualTeaching and Learning, Sebuah Panduan Awal dalam Pengembangan PBM. Yogyakarta: Rahayasa

Ningrum PK, (2013) Model pembelajaran kontekstual menggunakan media video

untuk meningkatkan kompetensi belajar mengubah pola blus pada siswa smk negeri 1 pengasih. Program Studi Pendidikan Teknik Busana Fakultas Teknik Universitas Negeri Yogyakarta;

https://eprints.uny.ac.id/32494/1/Putri\%20Kusuma\%20Ningrum\%2008513244015.pdf

Poespo,S. (2006). Reka Busana Kerja, Paduan Celana Panjang. PT. Gramedia visual Pustaka Utama.

Rusmalanur I, (2016) Upaya Mengefektifkan Teknik Praktis Pembuatan Pola Dengan Metode Picture and Picture pada SMK Negeri 3 Banda Aceh. 7 (1):

https://visipena.stkipgetsempena.ac.id/?journal=home\&page $=$ article $\&$ op $=v$ iew\&path $\% 5 \mathrm{~B} \% 5 \mathrm{D}=120$ ?journal=home \&page=article\&op=view \&path $\% 5 \mathrm{~B} \% 5 \mathrm{D}=120$

Silabus Pembuatan Pola jurusan Busana Butik Program Keahlian Tata Busana.(2006). Pemerintah Kota Semarang. Dinas Pendidikan. SMK N 6 Semarang.

Silberman,M. (2009). Active Learning 101 Strategi Pembelajaran Aktif Jakarta.

Soekarno. (2012). Buku Penuntun Membuat Pola Busana Tingkat Dasar. Jakarta: PT. Gramedja Pustaka Utama.

Sugiarti E, (2014) Penerapan Pembelajaran Langsung dan Team Assisted Individualization pada Sub Kompetensi Membuat Pola Secara Draping di SMK Katolik Mater Amabilis Surabaya. Fakultas Teknik Universitas Negeri Surabaya; 3 (1): p.( 1-10).

https://docplayer.info/314573-Endang-sugiarti-mahasiswa-s1-pendidikan-tata-busanafakultas-teknik-universitas-negeri-surabaya-e-sugiarti18es-gmail-com.html 
Yulita M, (2015) Upaya meningkatkan hasil belajar pembuatan pola melalui metode pembelajaran discovery learning dengan pendekatan scientific siswa kelas xi tata busana 2 smk negeri 6 palembang. Pemerintah Kota Palembang;

https://docdroid.net/p50t/abstrak-ptk-meri-yulita-busana.pdf

Yunita ED, (2015) Peningkatan hasil belajar membuat macam-macam pola gaun dengan metode pembelajaran team assisted individualization (TAI) di smk pgri batang. Fakultas Teknik Universitas Negeri Semarang;

https://text-id.123dok.com/document/nq77vloq-peningkatan-hasil-belajar-membuat-macammacam-pola-gaun-dengan-model-pembelajaran-team-assisted-individualization-tai-dismk-pgri-batang.html 